\title{
UNDERLYING CONTRADICTIONS IN THE SUPREME COURT'S CLASSIFICATION OF DEFAMATION
}

\author{
George C. Christie*
}

The Supreme Court contmues to spin a web in which the standard of proof of hability in defamation cases depends on the characterization of the plamtiff as either a public official or a public figure on the one hand or a private person on the otlier. To many this distimction, particularly as developed in later cases, seems unwise. The purpose of this article, however, is not to attack directly this distinction and the fluctuatimg standards of proof to which it has led. It is to show that the theoretical basis for the distmction has been undermmed by the Court during the very same period it has been creating the public figure/private person dichotomy.

The web created by the Court's decisions entangles both plamtiffs and defendants in search of constitutional protection. It is submitted that the need for consistency between the cases construmg the first amendment $\mathrm{m}$ other contexts and the cases establishing standards of proof in defamation actions will force the Court to reconsider the path it has taken.

\section{BACKGROUND}

\section{A. A Brief Recapitulation of Gertz and Its Background.}

Seven years have elapsed simce the Court, in Gertz v. Robert Welch, Inc., ${ }^{1}$ put a halt to the seemingly constantly expanding scope of $\mathrm{New}$ York Times Co. v. Sullivan. ${ }^{2}$ In Sullivan the Court had held that, in order to recover for defamation, a plaintiff had to prove actual mahice ${ }^{3}$ on the part of the defendant. Sullivan had involved a plamtiff who was a prominent local public official, but in a well-known sequence of cases, the Court apphed Sullivan's elevated standard of proof to defa-

* James B. Duke Professor of Law, Duke University; Fellow, National Humanities Center, 1980-81. I wish to thank my friend and colleague, William W. Van Alstyne, for reading this manuscript and for his helpful comments.

1. 418 U.S. 323 (1974).

2. 376 U.S. 254 (1964).

3. In this context, actual malice means knowledge of falsehood, or recklessness in the sense of conscious indifference to truth. 
mation actions brought by lower-ranking public officials or former public officials-at least when the actions were based on statements about their official conduct. ${ }^{4}$ The Sullivan requirement was then extended to "public figures," even those who were not imvolved in politics. ${ }^{5}$ Indeed, in one privacy case, Time, Inc. v. Hill, ${ }^{6}$ the Court mdicated that a relatively unknown person could, by accidental involvement in an event of major newsworthiness, become a public figure, at least with regard to statements concerning the newsworthy event. Fimally, in Rosenbloom v. Metromedia, Inc., ${ }^{7}$ the Court applied the Sullivan standard in an action brought by a person who was unknown to the public but who had become involved in a minor newsworthy event; specifically, he had been arrested for selling allegedly obscene literature. There was no majority opinion, but Justice Brennan's plurality opinion seemed to presage the future: discussion of newsworthy events was to be constitutionally protected; and, at least when the defendant was a member of the news media, the Court would be reluctant to second-guess the defendant's conclusion about what was newsworthy.

Gertz ended this expansionary development, although the Court's opinion reaffirmed the applicability of the Sullivan requirement of actual malice in actions brought by public officials and public figures. In actions brought by so-called private figures, only some showing of fault was necessary. ${ }^{8}$ In these cases, however, a plaintiff could recover only actual dainages unless he could satisfy the actual malice requirement of Sullivan.9 The Court held that Elmer Gertz was not a public figure even though lie was a inoderately well-known lawyer who at one time had been actively involved in the National Lawyers Guild and had occasionally participated in matters of soine political importance im Chicago. ${ }^{10}$

Almost two years later, in Time, Inc. v. Firestone, 11 the Court, again taking a restrictive view of who is a public figure, held that the wife of "the scion of one of America's wealthier industrial families"12 was not a public figure in the context of an action she had brought for

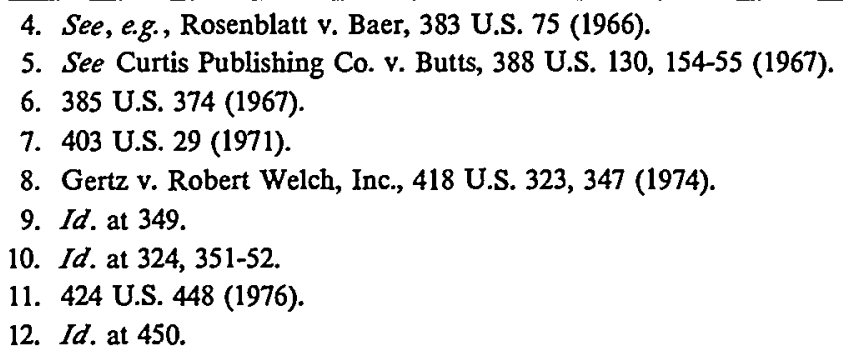

5. See Curtis Publishing Co. v. Butts, 388 U.S. 130, 154-55 (1967).

6. 385 U.S. 374 (1967).

7. 403 U.S. 29 (1971).

8. Gertz v. Robert Welch, Inc., 418 U.S. 323, 347 (1974).

9. Id. at 349 .

10. Id. at $324,351-52$.

11. 424 U.S. 448 (1976).

12. Id. at 450 . 
separate mamtenance; in which her husband had counterclaimed for divorce; and in which each had charged the other with adultery.

\section{B. The Response of the States.}

Although in a very important sense Gertz eased the restrictions that Sullivan had placed on a plaintiff in a defamation action, Gertz also increased the plaintiff's burden in cases that were never thought to be governed by Sullivan. It did so by requiring a showing of fault in all defamation actions and by limitimg a plaintiff to his actual damageshowever these may be determined-unless he could show malice on the part of the defendant. In the absence of such a showing of malice, neither presumed nor punitive damages could be awarded. ${ }^{13}$

Justice Powell, who wrote for the Court in Gertz, worded his opinion in terms of actions against a "publisher or broadcaster." 14 It was thus possible to argue that, at least in actions by private persons agamst non-1nedia defendants, the common law of defamation survived. A few state courts did in fact so hold and permitted an action to proceed without any proof of fault on the issue of truth or falsity on the part of the defendant. ${ }^{15}$ Most state courts that have considered the question, ${ }^{16}$ as well as the Restatement (Second) of Torts, ${ }^{17}$ have concluded that no such distinction is possible. Plaintiffs in all defamation actions nuust show some degree of fault on the part of the defendant. The only question is, how much? Most state courts have accepted the distinction drawn in Gertz between public officials and public figures on the one hand and private persons on the other. ${ }^{18}$ Others have refused to join

\section{418 U.S. at 349.}

14. Id. at 340 .

15. E.g., Harley-Davidson Motorsports, Inc. v. Markley, 279 Or. 361, 364-71, 568 P.2d 1359, 1362-65 (1977); see, e.g., Rowe v. Metz, 195 Colo. 424, 425-26, 579 P.2d 83, $84-85$ (1978); Calero v. Del Chem. Corp., 68 Wis. 2d 487, 499-506, 228 N.W.2d 737, 744-48 (1975).

16. See, e.g., Jacron Sales Co. v. Sindorf, 276 Md. 580, 590-94, 350 A.2d 688, 694-96 (1976); Ryder Truck Rentals v. Latham, 593 S.W.2d 334, 340 (Tex. Civ. App. 1980). See also Gray v. Allison Div., General Motors Corp., 52 Ohio App. 2d 348, 358, 370 N.E.2d 747, 754 (1977).

17. Restatement (SeCOND) of ToRTs $\$ \S 558,580 \mathrm{~B}$, Comment e (1977).

18. See, e.g., Peagler v. Phoenix Newspapers, Inc., 114 Ariz. 309, 312, 560 P.2d 1216, 1219-22 (1977); Dodrill v. Arkansas Democrat Co., 265 Ark. 628, 634, 590 S.W.2d 840, 842 (1979), cert. denied, 444 U.S. 1076 (1980); Cahill v. Hawaiian Paradise Park Corp., 56 Hawaii 522, 531, 543 P.2d 1356, 1363 (1975); Troman v. Wood, 62 Ill. 2d 184, 190, 340 N.E.2d 292, 296 (1975); Gobin v. Globe Publishing Co., 216 Kan. 223, 230, 531 P.2d 76, 82 (1975); Forrest v. Lynch, 347 So. 2d 1255, 1258 (La. Ct. App. 1977), cert. denied, 435 U.S. 971 (1978); Metronedia, Inc. v. Hillman, 285 Md. 161, 165-66, 400 A.2d 1117, 1120 (1979); Stone v. Essex County Newspapers, Inc., 367 Mass. 849, 854, 330 N.E.2d 161, 164 (1975); Madison v. Yunker, 589 P.2d 126, 130 (Mont. 1978); Thomas H. Maloney \& Sons v. E.W. Scripps Co., 43 Ohio App. 2d 105, 109, 334 N.E.2d 494, 498 (1974), cert. denied, 423 U.S. 883 (1975); Martin v. Grifin Television, Inc., 549 P.2d 85, 88 (Okla. 1976); Memphis Publishing Co. v. Nichols, 569 S.W.2d 412, 415 (Teun. 1978); Foster v. Laredo Newspa- 
the Court in its retreat from Rosenbloom v. Metromedia, Inc. ${ }^{19}$ Perhaps exhibiting greater sensitivity to the constitutional interests involved, these states have contmued to require a showing of mahice, at least when the defamatory statement concerns an issue of public imterest. ${ }^{20}$

New York has adopted an intermediate position. In Chapadeau v. Utica Observer-Dispatch, Inc., ${ }^{21}$ a case reminiscent of Rosenbloom, the New York Court of Appeals held that when a private imdividual is defauned in an article whose

content . . . is arguably within the sphere of legitimate public concern, which is reasonably related to matters warranting public exposition ... [the plaintiff] must establish, by a preponderance of the evidence, that the publisher acted in a grossly irresponsible manner without due consideration for the standards of information gathering and dissemination ordinarily followed by responsible parties. ${ }^{22}$

The plaintiff in Chapadeau was a high school teacher who had been arrested for possession of heroin and a hypodermic syringe. The defendant newspaper had incorrectly reported that the plaintiff had been arrested with two other persons during a party in a public park at which drugs and beer had been found. Holding that a teacher's influence with children made the arrest a natter of public interest, the court of appeals affirmed the lower court's dismissal of the action. ${ }^{23}$

The Chapadeau standard is reminiscent of Justice Harlan's suggestion, in his combined opmion in Curtis Publishing Co. v. Butts ${ }^{24}$ and Associated Press $v$. Walker, ${ }^{25}$ that public figures who were not public officials might be able to prevail if they could show gross negligence rather than malice. ${ }^{26}$ The grossly irresponsible standard has been applied by lower New York courts in cases involving a landlord who complamed of a television story about a dispute between himself and a

pers, Inc., 541 S.W.2d 809, 811 (Tex. 1976), cert. denied, 429 U.S. 1123 (1977); Taskett v. King Broadcasting Co., 86 Wash. 2d 439, 441, 546 P.2d 81, 83 (1976).

19. 403 U.S. 29 (1971).

20. See, e.g., Walker v. Colorado Springs Sun, Inc., 188 Colo. 86, 98-99, 538 P.2d 450, 457, cert. denied, 423 U.S. 1025 (1975); Aafco Heating \& Air Conditioning Co. v. Northwest Publications, Inc., 162 Ind. App. 671, 673, 321 N.E.2d 580, 583 (1974), cert. denied, 424 U.S. 913 (1976); Peisner v. Detroit Free Press, Inc., 82 Mich. App. 153, 163, 266 N.W.2d 693, 698-99 (1978); Schaefer v. State Bar, 77 Wis. 2d 120, 125, 252 N.W.2d 343, 346 (1977). See also Gay v. Williams, 486 F. Supp. 12 (D. Alaska 1979).

21. 38 N.Y.2d 196, 341 N.E.2d 569, 379 N.Y.S.2d 61 (1975).

22. Id. at 199,341 N.E.2d at 571,379 N.Y.S.2d at 64.

23. Id at 200,341 N.E. $2 \mathrm{~d}$ at $571-72,379$ N.Y.S.2d at $64-65$.

24. 388 U.S. 130 (1967).

25. 388 U.S. 130 (1967) (reported sub nom. Curtis Publishing Co. v. Butts).

26. 388 U.S. at 146-55. Justice Harlan, however, later abandoned that position in Rosenbloom v. Metrounedia, Inc., 403 U.S. 29, 68-69 (1971) (Harlan, J., dissenting)(arguing for a reasonable care standard); $c f$. id. at 72-78 (Harlan, J., dissenting) (actual malice required for award of punitive damages). 
tenant;:27 a doctor who brought an action after CBS-TV aired an interview with a former patient who had been treated with amphetamines; ${ }^{28}$ and an action against a newspaper that incorrectly reported the disposition of criminal proceedings brought against a major shareholder of a shopping inall who had been involved in an altercation with a bicyclist in the mall. ${ }^{29}$

\section{The Supreme Court's Development of Defamation Post-Gertz.}

Although some state courts have determined that the dichotomy between public officials and public figures on the one hand and private figures on the other inust, in some circumstances, give way to the public interest in free discussion, the Court thus far seems unwilling to return to Rosenbloom's newsworthiness test. Indeed, the Court has given every indication of wanting to permit the inaximum number of defamation cases to proceed under the Gertz neghigence standard by restricting the class of public figures. One case I have already referred to is Time, Inc. v. Firestone, decided in 1976.30 In the spring of 1979, the Court decided Hutchinson v. Proxmire ${ }^{31}$ and Wolston v. Readers Digest Association.32 Hutchinson involved a professor whose work on the emotional behavior of animals had been funded by the federal government. Some of this research involved the study of behavior patterns such as the clenching of jaws when the animals were exposed to certam stressful stimuli. Senator Proxmire sharply criticized the government funding of this research and awarded Hutchinson the "Golden Fleece Award." The Court ruled that Hutchinson was a private figure; the public's interest in the expenditure of government funds did not cause Hutchinson to be a public figure..$^{33}$

Wolston involved the nephew of Myra and Jack Noble, who were arrested in 1959 on charges of spying for the Soviet Union and who later pleaded guilty to charges of espionage. After the Nobles's arrest, Wolston was questioned by the Federal Bureau of Investigation (FBI) and was summoned before several grand juries. Having failed to appear before a grand jury in July of 1958, Wolston was held in conteinpt; given a suspended sentence; and placed on three year's probation conditioned on his cooperation with grand jury investiga-

27. Cottom v. Meredith Corp., 65 A.D.2d 165, 411 N.Y.S.2d 53 (1978).

28. Greenberg v. CBS, Inc., 69 A.D.2d 693, 419 N.Y.S.2d 988 (1979).

29. Grobe v. Three Village Herald, 69 A.D.2d 175, 420 N.Y.S.2d 3 (1979), affd, 49 N.Y.2d 932, 406 N.E.2d 491, 428 N.Y.S.2d 676 (1980).

30. 424 U.S. 448 (1976). See text accompanying notes 11-12 supra.

31. 443 U.S. 111 (1979).

32. 443 U.S. 157 (1979).

33. 443 U.S. at 135-36. 
tions of Soviet espionage. A number of newspapers reported these events. Although Wolston was identified as a Soviet agent in an FBI report in 1960, he was never prosecuted. Aside from the investigation in the late 1950s, Wolston had led a life of obscurity. In 1974, the dcfendant published a book entitled $K G B$ that named Wolston, among others, as a person who had been identified as a Soviet agent in the United States. Wolston then brought the defamation action. The district court classified Wolston as a public figure and granted summary judgment for Readers Digest. ${ }^{34}$ The court of appeals affirmed. ${ }^{35}$ The Supreme Court reversed, holding that Wolston was a private figure:

Petitioner's failure to appear before the grand jury and citation for contempt no doubt were "newsworthy," but the simple fact that these events attracted media attention also is not conclusive of the publicfigure issue. A private imdividual is not automatically transformed into a public figure just by becoming involved in or associated with a matter that attracts public attention. To accept such reasoning would in effect re-establish the doctrine advanced by the plurality opimion in Rosenbloom v. Metromedia, Inc. . . . .36

Although the Court was not prepared to state that one could never involuntarily become a public figure and thereby be subject to the application of Sullivan, it certainly showed a strong predeliction against finding such a situation to exist.

\section{The Contradiction}

\section{A. The Old Dominion Case.}

On the same day that the Court decided Gertz, it handed down its decision in Old Dominion Branch No. 496, National Association of Letter Carriers v. Austin. ${ }^{37}$ In that case the three plaintiff letter carriers, who were among a group of fifteen out of 435 who were not members of the local branch of the defendant union, were described as "scabs" in the umon newsletter and then likened to Esau, Judas, and Benedict Arnold. The newslettcr continued by quoting Jack London's definition of a "scab" as " 'a traitor to his God, his country, his family and his class." "38 The plaimtiffs had recovered substantial damages for defamation in the trial courts, and the Virginia Supreme Court had affirmed. ${ }^{39}$

34. 429 F.Supp. 167, 176, 180 (D.D.C. 1977), aff'd, 578 F.2d 427 (D.C. Cir. 1978), rev'd, 443 U.S. 157 (1979).

35. 578 F.2d 427 (D.C. Cir. 1978), rev'd, 443 U.S. 157 (1979).

36. 443 U.S. at 167.

37. 418 U.S. 264 (1974).

38. Id. at 268 (emphasis in original).

39. 213 Va. 377 , 192 S.E.2d 737 (1972), rev'd, 418 U.S. 264 (1974). 
On appeal, the Supreme Court reversed. Writimg through Justice Marshall, it held that the Sullivan standard was applicable because the statements in question had been made in the course of what was arguably a "labor dispute." 40 Thus on the same day that the Court in Gertz restricted the constitutional privilege enunciated in Sullivan to the category of public officials and public figures, it also lield that the Sullivan standard was.applicable to persons far less "public" than Mr. Gertz because of the context in which the alleged defamation had occurred. The Court gave no indication of whether the Sullivan standard might apply to statements in other special contexts. ${ }^{41}$

Most commentators have classified Old Dominion as a labor case and ignored its potential for general application. ${ }^{42} \mathrm{I}$ have elsewhere argued that this view is mistaken. ${ }^{43}$ To confine Old Dominion to labor disputes is to accept without qualm "a legal resolution under which speech is freer in the context of a labor dispute than in one of the paradigmatic first amendment situations-political disputes among private citizens." 44 As a matter of logic, not only speech about politics but also about foreigu policy and subjects such as securities regulation and consumer protection must be given the same protection.

\section{B. Carey v. Brown. 45}

In June 1980 the Court struck down an Illinois statute restricting residential picketing. The statute inade it unlawful for a person " to picket before or about the residence or dwelling of any person, except

40. 418 U.S. at $282-83$.

41. In reaching its conclusion, the Court relied on Linn v. Plant Guard Workers Local 114, 383 U.S. 53 (1966), a case decided before Sullivan had been extended beyond the category of public officials. In Linn the Court held that defamatory statements made about management officials during a union organizing campaign, although within the jurisdiction of the National Labor Relations Board, could also be the subject of an action for damages under state law, provided that the Sullivan standards were met and that actual damages were shown. State actions for defamation were thus not totally preempted by federal labor law. The Court in Old Dominion did not allude to the actual damage requirement of Linn. In Old Dominion the Court devoted most of its opinion to the issue of the degree of fault the plaintiffs would lave to show. One should note, however, that the Court went on to hold alternatively that the statements in the newsletter were not actionable because they involved mere expressions of opinion and the use of epithets. The Old Dominion case is discussed in greater detail, as is the Supreme Court's treatment of defamation since Sullivan, in Christie, Injury to Reputation and the Constitution: Confusion Amid Conficting Approaches, 75 Mich. L. REv. 43 (1976).

42. For references, see Christie, supra note 41, at 57 n.83. See also Christie, Defamatory Opinions and the Restatement (SeCOND) OF TORTs, 75 MiCh. L. Rev. 1621, 1624 n.15 (1977).

43. See Christie, supra note 41 , at 55-59.

44. Id. at $57 \mathrm{n} .83$.

45. 447 U.S. 455 (1980). Justice Rehnquist, joined by Chief Justice Burger and Justice Blackmun, dissented. Id at 472 . Justice Stewart wrote a brief concurring opinion. Id. at 471 . 
when the residence or dwelling is used as a place of business." "46 The statute by its express terms, however, did not apply " to a person peacefully picketing his own residence or dwelling and [did] not prohibit the peaceful picketing of a place of employment involved in a labor dispute or the place of holding a meeting or asseinbly on premises coininonly used to discuss subjects of general public interest." "47 In Carey v. Brown the Court upheld a lower court's decision that struck down the statute because the distinction between labor and non-labor disputes was considered untenable. 48

The Court relied heavily on Police Department $v$. Mosley, ${ }^{49}$ which involved an ordinance prohibiting picketing next to a school. The ordinance exempted "the peaceful picketing of any school involved in a labor dispute." 50 The Court of Appeals for the Seventh Circuit ruled the ordinance unconstitutional and the Court affirmed, stating " $[t]$ he central problein with Chicago's ordinance is that it describes permissible picketing in terms of its subject matter."51 The Court concluded:

above all else, the First Amendment means that government has no power to restrict expression because of its message, its ideas, its subject matter, or its content. . . .

... Selective exclusion from a public forum may not be based on content alone, and may not be justified by reference to content alone. 52

In Carey the appellants sought to distinguish Mosley by arguing that the government's interest in insuring the privacy of the liome is greater than its interest in preventing disruption at schools, and that the state lias an interest in providing special protection for labor protestsevidenced by the special concern that federal and state law had long displayed for such activity. ${ }^{53}$ The Court did not accept these arguments, declaring unequivocally:

The central difficulty with this argument is that it forthrightly presupposes that labor picketing is more deserving of First Amendment protection than are public protests over other issues, particularly the important economic, social, and political subjects about which these appellees wish to demonstrate. We reject that proposition. ${ }^{54}$

46. Id. at 457 (quoting Act of June 29, 1967, § 1, ILL. REv. Stat. ch. 38, § 21.1-2 (1977)).

47. 447 U.S. at 457 (emphasis added).

48. See Brown v. Scott, 602 F.2d 791 (7th Cir. 1979), aff'd sub nom. Carey v. Brown, 447 U.S. 455 (1980).

49. 408 U.S. 92 (1972).

50. Id. at 93 .

51. Id. at 95 .

52. Id. at $95-96$.

53. 447 U.S. at 464-67.

54. Id. at 466. Though the Court in Carey placed major rehance on Mosley, it also referred 
Admittedly, of course, the Court's record in dealing with situations in which the content of speech provided the basis for differential treatinent has not been totally consistent. One need only refer to Lehman $v$. City of Shaker Heights, ${ }^{55}$ another case decided on the same day as both Gertz and Old Dominion. In Lehman the Court upheld the refusal of a public rapid transit system that sold advertising space on the sides of its vehicles to accept pohtical advertising. One might also note the inore recent Young v. American Mini Theatres, Inc. ${ }^{56}$ in which the Court upheld a zoning ordmance restricting the areas in which "adult" motion picture theatres could be operated, ${ }^{57}$ and the even more recent $F C C v$. Pacifica Foundation, ${ }^{58}$ in which a sharply divided Court upheld the FCC's efforts to police radio broadcasters' use of language that is "patently offensive" but not obscene. 59

Probably no one could reconcile all the Court's recent activity concerning the regulation of speech according to its content. It is certainly

to Cox v. Louisiana, 379 U.S. 536 (1965). 447 U.S. at 470 . In Cox a conviction based on a statute prohibiting obstruction of public passages was reversed. Although the statutory prohibition applied to all obstructions other than labor organizations engaged in lawful picketing, the statute was applied unevenly because the city officials of Baton Rouge, where the obstruction took place, exercised "unfettered discretion" in issuing permits for certain meetings and parades. 379 U.S. at 553-58. Significantly, the Court commented in a footnote that the statute's exception for labor picketing, "points up the fact that the statute reaches beyond inere traffic regulation to restrictions on expression." Id. at $556 \mathrm{n} .14$. The case also involved a breacl of the peace conviction under another statute struck down as overbroad. In a companion case arising out of the sane set of events and involving a statute restricting picketing on or near a courthouse, the Court upheld the statute but reversed the conviction because on the facts of the case there was evidence that the police had advised the appellants that the demonstration would be permitted. Cox v. Louisiana, 379 U.S. 559 (1965).

55. 418 U.S. 298 (1974).

56. 427 U.S. 50 (1976).

57. Cf. New York State Liquor Authority v. Bellanca, 101 S. Ct. 2599 (1981) (under the 2Ist amendinent the state lias the power to regulate the circumstances under which liquor is sold and, therefore, may prohibit nude dancing in establishments licensed by the state to serve liquor). But of. Schad v. Borough of Mount Ephraim, 101 S. Ct. 2176 (1981) (zoning ordinance prohibiting live entertainment-in this case nude dancing-in the commercial strip of the borough held unconstitutional).

58. 438 U.S. 726 (1978).

59. The Court not only sphit five to four but there were important differences among those in the majority. Justice Stevens, writing the plurality opimion, found that because the speecl at issue was " 'vulgar,' 'offensive,' and 'shocking," " 438 U.S. at 747, it was not entitled to absolute constitutional protection, and that the Court inust therefore consider the context in which the speecli was used. Because the case involved radio broadcasting, an area traditionally subject to government regulation, Justice Stevens concluded that the FCC acted constitutionally in assessing sanctions against the radio station. Id. at 748-50. Justice Powell, joined by Justice Blackmun, although otherwise concurring in the opinion, could not "subscribe to the view that the Justices of this Court are free generally to decide on the basis of its content which speech protected by the First Ainendment is most valuable . . . and 'less valuable' . . ." Id. at 761. 
not my purpose to attempt to do so. The complexity of the task would be increased by the Court's contmued erosion of the distinction between commercial and noncommercial speech. ${ }^{60} \mathrm{My}$ only purpose is the more limited one of asking how, if states may not imsert a special "labor dispute" exemption in an otherwise presumably vahid ban on picketing in certain locations, can the Court or the Congress imsert a labor dispute exception into what wonld otherwise be vahd state law restricting defamatory utterances? ${ }^{61}$

\section{IMPLICATIONS FOR THE FUTURE}

It is impossible, given Carey v. Brown, to ignore Old Dominion as simply a labor dispute case. Carey at least stands for the proposition that discussion in labor disputes cannot, consistent with the Constitution, be more free than in other areas of public interest. If private persons alleging defamation im the context of a labor dispute must meet the Sullivan standard, so must the plaintiffs imvolved in disputes concerning other matters of public interest. And, as we have seen, a number of states have so lield. 62

Furthermore, Carey also suggests the broader proposition that all defamation actions must be subject to the same standard of proof of hability regardless of the context. Anything else is content regulation. Indeed, there are practical reasons for so liolding. Deciding what is a matter of public interest is a difficult question. Permitting the media to decide this question presents difficulties, and these problems undoubtedly are one reason for the retreat from Rosenbloom. But the idea that judges are to make this decision for the public also creates difficulties. One is given little confidence im their judgment when one examines their efforts at deciding who was a public figure in the Gertz, Firestone, Hutchinson, and Wolston cases. A good argument can be made that all of these cases involved public figures.

60. This erosion is reflected in a pair of recent cases, Consolidated Edison v. Public Serv. Comm'n, 447 U.S. 530 (1980), and Central Hudson Gas \& Elec. Corp. v. Public Serv. Comm'n, 447 U.S. 557 (1980), decided the same day as Carey in June 1980. One might also notc John Donnelly \& Sons v. Campbell, 639 F.2d 6 (1st Cir. 1980), affd mem, 49 U.S.L.W. 3978 (U.S. July 2, 1981) (No. 80-1597), in which, in late December 1980, the Court of Appeals for the First Circuit struck down a Maine statute prohibiting all roadside billboards except those advertising religious or civic events, election campaign signs, and signs erected by historical and cultural institutions. See also National Bank v. Belloti, 435 U.S. 765 (1978).

61. We are considering, of course, a case where a state has elected, under the Gertz standard, to require private individuals in defanation actions to slow neghigence on the part of the defendant. On the issue of content regulation, see Hudgens v. NLRB, 424 U.S. 507 (1976), cited by Justice Stewart in his concurring opinion in Carey v. Brown, 447 U.S. 455, 472 (1980).

62. Sec note 20 supra. 
The difficulties involved in all these issues suggest the need for a single standard for all defamation actions-a standard in which the public figure and the public interest questions play no part. Elsewhere I have discussed the reasons why I believe the Court will eventually opt for a universal application of the Gertz negligence standard. ${ }^{63}$ My own personal preference, however, increasingly grows in favor of applying the Sullivan standard to all defamation actions. This standard provides maximum protection for freedom of discussion and preserves the plaintiff's right to redress when the defendant's conduct is particularly reprehensible.

63. Christie, supra note 41 , at 63-67. 
